\title{
The Chemical Composition of Some Waters from Lowland Lakes in Shropshire, England
}

\author{
By EVILLE GORHAM, Freshwater Biological Association, Ambleside, England
}

(Manuscript received September 24, I956)

\begin{abstract}
Analyses are presented for $\mathrm{pH}, \mathrm{Na}, \mathrm{K}, \mathrm{Ca}, \mathrm{Mg}, \mathrm{HCO}, \mathrm{Cl}, \mathrm{SO}_{4}, \mathrm{NO}_{3}, \mathrm{PO}_{4}$ and $\mathrm{SiO}_{2}$ in surface waters from eight Shropshire meres subject to.dense water blooms of blue-green algae. Samples were taken in November 1954 and June I95s. It appears likely that the chemistry of the waters reflects increasing alteration of rain water composition by solution of the products of rock and soil weathering, chiefly calcium bicarbonate. Magnesium was the only major ion observed to vary greatly with season of sampling. Potassium was anomalous in being more abundant in the dilute waters, where it accounted for an unusually high proportion of total salts. An attempt has been made to relate the chemical composition of the various waters to local geological and physiographical variations.
\end{abstract}

The meres around Ellesmere in Shropshire have long been known for the frequency with which they. "break", to use the local term for a sudden development of water-bloom owing to the growth of immense numbers of blue-green algae. Philuss (1883) and GRIFFTHS (I925) have described the phytoplankton of these waters, but apart from these studies little is known of their ecology. In order to learn something further of the environment provided by these meres, a chemical survey of their waters was carried out in November 1954 and again in June I955.

\section{The area}

The meres lie in the great Midland plain of central England, at a little less than 100 metres above sea level. Annual rainfall is in the vicinity of 70 centimetres, of which evaporation probably accounts for about so centimetres (Penman 1950). The early spring months are usually the driest. Mean monthly temperature at Shrewsbury nearby varies from about $4.5^{\circ} \mathrm{C}$ in winter to about $16^{\circ} \mathrm{C}$ in summer.

The geological substrata are of Triassic age (Pocock and WRAY I925, EDMUNDS and OAKLEY 1947). Ellesmere Mere overlaps the boundary between Bunter and Keuper sandstones, while Blake, Kettle and White Meres are on the Keuper waterstones. Newton Mere is on the border between these and the Keuper marl, which lies beneath Cole, Crose and Sweat Meres. These rocks are overlain here by glacial drift, in which the meres occupy hollows which may represent kettleholes. It is predominantly boulder clay or till around Ellesmere Mere and White Mere, with Newton, Blake and Kettle Meres on the boundary between this and glacial sands and gravels. Cole, Crose and Sweat Meres are all well inside the borders of the latter deposits, and it is these three meres which are marked on the $I: 25000$ Ordnance Survey map (sheet 33/43) as having marshy shores. Presumably the boulder clay in the substrata of 
the other meres is more favourable to the maintenance of a deep, steeply-sloping basin than are the sands and gravels.

The soils of the district have been described by Crompton and OSMOND (I954). Most of the meres lie on brown earths of low base status (Baschurch series), although gley soils (Salop series) predominate around Ellesmere Mere, and peats are recorded in the vicinity of Kettle, Cole, Crose and Sweat Meres. The upper soil horizons are in general free from calcium carbonate, and just on the acid side of the neutral point. Both soil groups are usually cultivated, arable or mixed farming being more common on the brown earths, and dairy farming on the gleys, which are highly suitable for pasturage.

In such a flat area drainage is very sluggish. Kettle Mere and Blake Mere are joined by a small ditch, and Sweat Mere is fed by a stream from Crose Mere, but the other waters appear to have no appreciable inflow streams. Only Cole, Crose and Sweat Meres possess even small outflow streams.

\section{Methods}

Surface water samples were collected during November I954 and June 1955, in polythene bottles. On return to the laboratory the waters were filtered through washed Whatman 54I papers, the initial portion being discarded. Analytical methods were those given by GorHam (I955), dissolved silica being estimated by visual colorimetry using the ammonium molybdate procedure and reduction to molybdenum blue.

It may be mentioned that at the time of sampling in June I955, only Newton, Blake and especially Kettle Mere showed abundant growths of algae. These were identified by Dr J. W. G. LuND as Sphaerocystis schroeteri agg., Coelosphaerium naegelianum and Oscillatoria redekei respectively.

\section{Results}

The analytical data are given in Table I in order of increasing total salt concentrations, the major ions as milli-equivalents per litre, and dissolved nitrate, phosphate and silica as

Table I. Ionic concentrations in some waters from Shropshire meres, and in Lake District rain

\begin{tabular}{|c|c|c|c|c|c|c|c|c|c|c|c|c|c|c|}
\hline \multirow{2}{*}{ Lake } & \multirow{2}{*}{ Date } & \multicolumn{2}{|c|}{ pH } & $\begin{array}{l}\text { Total } \\
\text { salts }\end{array}$ & $\mathrm{Na}$ & $\mathbf{K}$ & $\mathrm{Ca}$ & $\mathbf{M g}$ & $\mathrm{HCO}_{3}$ & $\mathrm{Cl}$ & $\mathrm{SO}_{4}$ & $\begin{array}{l}\mathrm{NO}_{3} \\
-\mathrm{N}\end{array}$ & $\mathrm{PO}_{4}-\mathrm{P}$ & $\mathrm{SiO}_{2}$ \\
\hline & & $\begin{array}{c}\text { filter- } \\
\text { ed }\end{array}$ & $\begin{array}{c}\text { aerat. } \\
\text { ed }\end{array}$ & \multicolumn{8}{|c|}{ milliequivalents per litre } & \multicolumn{3}{|c|}{ parts per million } \\
\hline $\begin{array}{r}\text { Lake District } \\
\quad \text { rain } \ldots \ldots\end{array}$ & $\begin{array}{l}\text { May- } \\
\text { Oct. '54 }\end{array}$ & $4 \cdot 5$ & - & 0.158 & 0.083 & 0.005 & 0.015 & 0.016 & nil & 0.092 & 0.066 & $<0.02$ & $<0.001$ & \\
\hline Newton Mere & $\begin{array}{l}\text { Nov. '54 } \\
\text { June '55 }\end{array}$ & 6.8 & 7.4 & $\begin{array}{l}1.08 \\
1.06\end{array}$ & $\begin{array}{l}0.35 \\
0.37\end{array}$ & $\begin{array}{l}0.21 \\
0.20\end{array}$ & $\begin{array}{l}0.36 \\
0.37\end{array}$ & $\begin{array}{l}0.15 \\
0.11\end{array}$ & $\begin{array}{l}0.25 \\
0.30\end{array}$ & $\begin{array}{l}0.4^{6} \\
0.4^{2}\end{array}$ & $\begin{array}{l}0.35 \\
0.30\end{array}$ & $\begin{array}{l}0.03 \\
0.05\end{array}$ & $\begin{array}{l}0.33 \\
0.45\end{array}$ & $\begin{array}{l}1.0 \\
0.4\end{array}$ \\
\hline Blake Mere.. & June '55 & 7.2 & 7.6 & I.I 7 & 0.33 & 0.19 & 0.52 & 0.12 & 0.54 & $0.4^{\circ}$ & 0.23 & 0.02 & 0.01 & 0.4 \\
\hline Kettle Mere. & June '55 & 7.1 & $7 \cdot 6$ & 1.25 & 0.33 & 0.22 & $0.5^{8}$ & 0.12 & 0.57 & 0.39 & 0.28 & 0.05 & 0.004 & I.o \\
\hline $\begin{array}{l}\text { White Mere } \\
\text { Ellesmere }\end{array}$ & $\begin{array}{l}\text { Nov. '54 } \\
\text { June '55 }\end{array}$ & $7 \cdot 5$ & 8.0 & $\begin{array}{l}2.12 \\
2.13\end{array}$ & $\begin{array}{l}0.36 \\
0.36\end{array}$ & $\begin{array}{l}0.13 \\
0.13\end{array}$ & $\begin{array}{l}1.37 \\
1.50\end{array}$ & $\begin{array}{l}0.26 \\
0.12\end{array}$ & $\begin{array}{l}1.04 \\
1.12\end{array}$ & $\begin{array}{l}0.47 \\
0.44\end{array}$ & $\begin{array}{l}0.59 \\
0.59\end{array}$ & $\begin{array}{l}0.16 \\
0.03\end{array}$ & $\begin{array}{l}0.05 \\
0.002\end{array}$ & $\begin{array}{l}2.2 \\
2.2\end{array}$ \\
\hline Mere...... & $\begin{array}{l}\text { Nov. '54 } \\
\text { June '55 }\end{array}$ & 7.6 & 8.1 & $\begin{array}{l}2.52 \\
2.50\end{array}$ & $\begin{array}{l}0.46 \\
0.49\end{array}$ & $\begin{array}{l}0.27 \\
0.25\end{array}$ & $\begin{array}{l}1.45 \\
1.52\end{array}$ & $\begin{array}{l}0.37 \\
0.22\end{array}$ & $\begin{array}{l}\mathrm{I} .47 \\
\mathrm{I} .48\end{array}$ & $\begin{array}{l}0.54 \\
0.53\end{array}$ & $\begin{array}{l}0.42 \\
0.46\end{array}$ & $\begin{array}{l}0.05 \\
0.05\end{array}$ & $\begin{array}{l}0.4^{8} \\
0.4^{0}\end{array}$ & $\begin{array}{l}0.9 \\
2.0\end{array}$ \\
\hline Cole Mere... & $\begin{array}{l}\text { Nov. '54 } \\
\text { June '55 }\end{array}$ & 7.6 & 8.2 & $\begin{array}{l}3.00 \\
3.11\end{array}$ & $\begin{array}{l}0.46 \\
0.44\end{array}$ & $\begin{array}{l}0.12 \\
0.13\end{array}$ & $\begin{array}{l}1.95 \\
2.34\end{array}$ & $\begin{array}{l}0.49 \\
0.21\end{array}$ & $\begin{array}{l}\text { I. } 84 \\
\text { I.94 }\end{array}$ & $\begin{array}{l}0.55 \\
0.52\end{array}$ & $\begin{array}{l}0.56 \\
0.62\end{array}$ & $\begin{array}{l}0.14 \\
0.28\end{array}$ & $\begin{array}{l}0.10 \\
0.03\end{array}$ & $\begin{array}{l}1.8 \\
1.6\end{array}$ \\
\hline Crose Mere.. & $\begin{array}{l}\text { Nov. '54 } \\
\text { June '55 }\end{array}$ & 8.I & 8.3 & $\begin{array}{l}4.77 \\
4.68\end{array}$ & $\begin{array}{l}0.5^{\circ} \\
0.4^{8}\end{array}$ & $\begin{array}{l}0.15 \\
0.14\end{array}$ & $\begin{array}{l}3.25 \\
3.55\end{array}$ & $\begin{array}{l}0.88 \\
0.52\end{array}$ & $\begin{array}{l}3.04 \\
3.04\end{array}$ & $\begin{array}{l}0.60 \\
0.56\end{array}$ & $\begin{array}{l}\mathrm{I} .08 \\
\mathrm{I} .04\end{array}$ & $\begin{array}{l}0.20 \\
0.29\end{array}$ & $\begin{array}{l}0.1 \text { I } \\
0.04\end{array}$ & $\begin{array}{l}4.0 \\
2.4\end{array}$ \\
\hline Sweat Mere & June '55 & $7 \cdot 4$ & 8.1 & 4.68 & 0.46 & $0.1 \mathrm{I}$ & 3.68 & $0.4^{6}$ & 2.96 & 0.53 & 1.12 & 0.25 & 0.07 & 6.7 \\
\hline$\frac{\text { Newton Mere }}{\text { Rain }}$ & & & & 6.8 & $4 \cdot 3$ & 41.0 & 24.4 & 8.1 & $\infty$ & 4.8 & 4.9 & & & \\
\hline$\frac{\text { Crose Mere }}{\text { Rain }}$ & & & & 29.9 & 5.9 & 29.0 & 226.7 & 43.8 & $\infty$ & 6.3 & 16.1 & & & \\
\hline
\end{tabular}

Tellus IX (1957), 2 
parts per million of $\mathrm{N}, \mathrm{P}$ and $\mathrm{SiO}_{2}$. For comparison, Lake District rain (GoRHaM I955) is also included, and the ratios of concentrations in Newton and Crose Meres to rain have been calculated in the last two rows of Table $\mathrm{r}$.

There is a considerable range of total salt concentration in these waters, which vary between $\mathrm{I} .06$ and $4.77 \mathrm{~m}$.equiv./1. In all but Newton Mere, and especially in the richer waters, calcium and bicarbonate are distinctly dominant, ranging from 0.38 to 3.68 , and 0.25 to 3.04 m.equiv. 1 . respectively. In Newton Mere sodium (0.36 m.equiv./l) about equals calcium, and both chloride ( 0.44 m.equiv. 1 ) and sulphate (0.33 m.equiv. $/ 1)$ exceed bicarbonate $(0.28 \mathrm{~m}$.equiv./1). Among the metal cations magnesium is least plentiful in the more dilute waters (about o.I2 m.equiv./1), but increases greatly in the more concentrated samples; whereas potassium, which exceeds magnesium in the dilute waters, declines with increasing total salt concentration, from about 0.2 to a little more than 0.1 m.equiv. 1 , and in the richest waters is by far the least important of the major cations. In the three most dilute waters, from Newton, Blake and Kettle Meres, chloride (about 0.4 m.equiv./1) exceeds sulphate (about 0.3 m.equiv./1); in the intermediate waters the situation is rather variable; and in the two richest samples, from Crose and Sweat Meres, sulphate rises sharply to about double the chloride values (about I.I and 0.6 m.equiv./1 respectively).

Nitrate nitrogen is generally low in the three dilute waters $(0.02-0.05 \mathrm{ppm} N$ ), but rises considerably in the three waters richest in total salts (0.14-0.29 ppm N). Phosphate phosphorus is rather variable, being relatively low $(0.002-0.1$ I ppm P) in all but Newton and Ellesmere Meres $(0.3-0.5 \mathrm{ppm}$ P), particularly in summer. Silica tends in general to increase with increasing total salt concentration, from $0.4-\mathrm{I} .0 \mathrm{ppm} \mathrm{SiO}_{2}$ in the three dilute samples to as much as $6.7 \mathrm{ppm}$ in Sweat Mere.

$\mathrm{pH}$ is in all cases but one (Newton Mere before aeration, $\mathrm{pH}$ 6.8) on the alkaline side of neutrality, and increases with total salt concentration (largely dependent upon an increase in calcium bicarbonate). Upon aeration an increase of $0.2-0.7 \mathrm{pH}$ units is observed, due to expulsion of dissolved carbon dioxide.
The maximum change was recorded from Sweat Mere, where the sample had to be taken just on the edge of the very luxuriant reedswamp surrounding this mere.

\section{Discussion}

The most striking feature of the present results is the great variation in ionic concentrations, particularly of calcium and bicarbonate, in these meres, which are all close together, rather similar in general appearance, and liable to dense algal water blooms. If the proportional contributions of individual ions to the total cation or anion concentrations are calculated, as in Table 2 , it is clear

Table 2. Total salt concentrations and ionic proportions in some waters from Shropshire meres, and in Lake District rain

\begin{tabular}{|c|c|c|c|c|c|c|c|c|}
\hline \multirow{4}{*}{$\begin{array}{l}\text { Lake Dis- } \\
\text { trict rain } \\
\text { Newton }\end{array}$} & \multirow{2}{*}{$\begin{array}{c}\text { Total } \\
\text { salts } \\
\text { m.equiv } \\
\text { per } 1\end{array}$} & $\mathrm{Na}$ & $\mathrm{K}$ & $\mathrm{Ca}$ & \multicolumn{4}{|c|}{$\mathrm{Mg}\left|\mathrm{HCO}_{3}\right| \mathrm{Cl} \mid \mathrm{SO}_{4}$} \\
\hline & & \multicolumn{7}{|c|}{$\begin{array}{l}\text { milliequivalents per cent } \\
\text { of total cations or anions }\end{array}$} \\
\hline & 0.17 & $5^{2}$ & 3 & 9 & to & nil & $5^{8}$ & 42 \\
\hline & & & & & & & & \\
\hline Mere.... & I.07 & 34 & 19 & 35 & 12 & 26 & $4 \mathrm{I}$ & 30 \\
\hline Blake Mere & I.I7 & 28 & I6 & 45 & Io & $4^{6}$ & 34 & 20 \\
\hline Kettle Mere & 1.25 & 26 & 18 & 46 & 10 & $4^{6}$ & $3 I$ & 23 \\
\hline White Mere & 2.13 & I7 & 6 & 68 & 9 & $5 I$ & $2 \mathrm{I}$ & 28 \\
\hline $\begin{array}{l}\text { Ellesmere } \\
\text { Mere..... }\end{array}$ & 2.51 & 19 & I I & 59 & \pm 2 & 59 & 22 & 18 \\
\hline Cole Mere. & 3.06 & I 5 & 4 & 70 & 12 & 63 & I 8 & 20 \\
\hline Crose Mere. & 4.73 & II & 3 & 72 & 15 & 64 & I 3 & 23 \\
\hline
\end{tabular}

that with increasing total concentration there is a marked rise in the percentage of calcium, balanced by a similar rise in bicarbonate, and a sharp fall in sodium, balanced by an equivalent fall in chloride. Such a picture strongly suggests a progressive modification of rain water composition by addition of materials weathered from soil minerals, and the inclusion of Lake District rain in Table 2 provides a basis for further comparison. While the Lake District is physiographically a very different sort of area from the Shropshire plain, it seems unlikely that the differences in rain water chemistry will be of sufficient magnitude to vitiate the rather crude comparisons to be made. On general grounds one might expect Shropshire rain to be somewhat more concentrated, owing to the drier climate; and the sulphate/chloride ratio might perhaps be higher, with the Ellesmere area a bit 
farther from the sea and rather more exposed to atmospheric pollution from industry.

Table 2 demonstrates clearly that the dilute Shropshire waters exhibit ionic proportions much more like those of rain than the proportions in the richer waters. Not only are sodium and chloride high, but the latter is distinctly in excess of sulphate, as in Lake District rain but contrary to the case in the richer meres. Nevertheless, even in Newton Mere the composition of the rain appears to be greatly altered by the time it reaches the mere. Taking Lake District rain for comparison, calcium has increased from 9 to 35 per cent, and bicarbonate from nil to 26 per cent, a rise of 26 per cent in both cases. This increase in calcium bicarbonate is exactly balanced by the virtual absence from Newton Mere of hydrogen ions, which account for 26 per cent of total cations in Lake District rain. Potassium is also greatly enriched in the water of Newton Mere, accounting for almost a fifth of total cations as against 3 per cent in rain.

Examining the matter in another way, the ratios in Table I indicate that in Newton Mere calcium is increased 24 -fold, potassium 4I-fold, magnesium only 8 -fold and sodium, chloride and sulphate between 4 and 5-fold over the levels in Lake District rain. In Crose Mere the enrichment factors are increased greatly in the case of calcium (227-fold), magnesium (44-fold) and sulphate (I6-fold); but that of potassium - initially high - is reduced (to 29-fold) owing to a drop in absolute concentration, and the factors for sodium and chloride are only slightly increased (to about 6-fold).

If Newton Mere is claimed to reflect rain composition, its high proportions of sodium and chloride-chiefly responsible for the rain resemblance-must be assumed to derive almost wholly from rain, although 4-5 times as concentrated in the mere water. While the balance between these two ions is much the same as that in rain water, it is not possible on this ground to separate clearly atmospheric supply from that which might come from salt lake deposits (such as those known to exist in nearby districts), since the rain itself receives its sodium and chloride in almost equivalent amounts from sea spray (Gorham I955). However, it may be reTellus IX (1957), 2 marked that the sodium/chloride ratio in the meres is very close to that in sea water ( 0.84 as against 0.85 , Lake District rain ratio 0.90 ). Apart from such considerations, if reasons can be adduced in favour of a strong concentration of rain water by the time it has reached the meres, there will be good grounds for assuming their sodium and chloride to be supplied from this source.

Two such reasons can be given. The most important concentration factor is probably to be found in the high proportion of rainfall which is evaporated in this area. For instance, with a rainfall of 70 centimetres and evaporation of so centimetres, a concentration factor of 3.5 would result. The second possibility is that there may be another important atmospheric salt supply apart from that in rain. Vegetation capture of hygroscopic salt particles from the atmosphere, even during dry weather, seems very likely from the observations of ERIKSSON (I9S5), and analyses by TAMM (I953) suggest that the sodium concentrations of rain may often be more than doubled after it has washed through the forest canopy. However, these data come from Sweden, a country largely covered by coniferous forest, which might well be a more efficient collector for salt particles than the arable land and pastures of Shropshire. Nevertheless, bearing in mind the factors mentioned above, and the possibility that Shropshire rain is more concentrated than Lake District rain, it may be concluded that there are strong grounds for believing that the sodium chloride in the Shropshire meres does in fact come mostly from atmospheric sources, and that the differences in ionic proportions among these waters do reflect a progressive alteration of rain water by solution of the products of rock and soil weathering.

The marked differences in accumulation of such weathering products as calcium, magnesium and potassium in the various meres remain to be accounted for. While there is little evidence to go on, the drift map of the Geological Survey (inch-to-themile, sheet 138) and the topographical map of the Ordnance Survey (I :25,000, sheet 33/43) provide some basis for reasonable conjecture. It can be seen that the three dilute meres (Newton, Blake and Kettle) lie in a compact group surrounded on three sides by 
the others, and it seems likely that their drainage areas are relatively restricted. Thus surface run-off may perhaps play a larger part in these meres than deep percolation through the less leached subsoils. On the other hand, the three richest meres (Cole, Crose and Sweat) are the only ones with any appreciable outflow streams, which suggests that they may be more continuously fed by reserves of ground water. Their location well inside the borders of the more pervious glacial sand and gravel deposits may be inferred as more favourable to such ground water supply by slow percolation. The slightly increased sodium and chloride concentrations in the waters of these meres, pointing to a greater degree of evaporation, may also be the result of longer (and deeper) soil percolation. Another point to be noticed with regard to these three meres is their situation above the Keuper marls, while the others lie on top of sandstones. However, in view of the thickness of the drift (more than 45 metres around Ellesmere, and about 60 metres at Welshampton 3 kilometres to the east, Pocock and WRAY 192s), it seems unlikely that this is of any great significance.

A phenomenon of interest in the magnesium results is the marked seasonal difference in concentration, the June values being on the average only about 70 per cent of the November ones. This reduction is compensated by a proportionally much slighter increase in the far more plentiful calcium ion. The only possibility occurring to the author is that differences in ground water level may be involved, with drainage passing through different soil levels. In this connexion, the soil analyses of CrOMPTON and OSMOND (I954) show a marked increase of exchangeable magnesium in the deeper horizons of several soil profiles, without any equivalent rise in exchangeable calcium. Minute dolomite crystals are known to be abundant in some Keuper deposits, and these may be of importance for magnesium supply.

A curious feature of the analyses is the decline in potassium with increasing salt concentration. This element is remarkably plentiful in the Shropshire waters, ranging from 0.22 to $0.1 \mathrm{I}$ m.equiv. $/ 1$ and from 19 to 3 per cent of total cations. In the average fresh water of the world (CONWAY 1942) a concentration of 0.08 m.equiv. $/ 1$ accounts for 3.4 per cent of total cations; and in Lake District waters over a wide range of concentrations potassium seldom rises above 4 per cent (MACKERETH 1957). Again, in the absence of concrete evidence one can do no more than speculate as to the factors influencing potassium levels in these meres; however, the following tentative hypothesis may perhaps serve to suggest lines for further investigation.

It is known that Keuper deposits, in particular the marls, are rich in clay (EDMUNDs and OAKLEY 1947; see also CROMPTON and OSMOND 1954 on clay content of soils); and these deposits, laid down under arid climatic conditions, were covered by salt lakes and then shallow seas for a long time during the Jurassic period. According to Clarke (I924) and Conway (1943) such conditions are extremely favourable to fixation of potassium in the form of glauconite. This mineral is produced by combination of potassium with silicates of iron and aluminium, released from fine soil particles through weathering processes believed to be aided by decomposing organic matter, which was presumably plentiful in such shallow seas. Such a process might well lead to an abundance of potassium in these Triassic deposits.

However, even assuming such abundance, an explanation must still be sought for the release of greater quantities into the dilute than into the concentrated mere waters. As a further suggestion, it might be expected that glauconite - fairly resistant to weathering (CONWAY 1943) - would not be attacked severely while carbonates are still available in large amounts to neutralize the weathering acids, as is probably the case with the richer meres. However, it must be admitted that the dilute waters are not as high in dissolved silica as the more concentrated samples. This could be taken to controvert any argument for greater silicate decomposition in the drainage areas of the more dilute meres, but on the other hand the much greater solubility of silica at high $\mathrm{pH}$ values may well account for its higher concentrations in the rather more alkaline waters of the richer meres. Another possibility is that lakes on the sands and gravels, poorer in fine particles and so perhaps in potassium-rich minerals, 
may receive less potassium from such a source. White Mere, on boulder clay but poor in potassium, forms an exception, but since the lakes on boulder clay are all so close to the boundary between it and the sands and gravels, it is difficult to say whether one or the other type of deposit may exert a predominant influence.

In conclusion it may be remarked that none of the present analyses yield any clue to the biological variation within these meres recorded by PhiLuips (1883). While the general richness in mineral nutrients may be considered as an important factor in producing frequent algal water blooms, there exist local differences which bear no apparent relation to the chemistry of the mere waters as far as at present known. For example, Newton Mere, with the most dilute water, had a reputation for "breaking" several times in the year; another dilute water, Kettle Mere, also was known to break frequently; but Blake Mere, the third dilute water, and connected with Kettle Mere by a small ditch, was stated by Phillips (I883) to be never known to break, and Gruffirhs (1925) claimed that it had only begun to break within recent years. Cole Mere, one of the richest in salts, was known to Philuips as breaking annually, and Crose and Ellesmere Meres were observed breaking, although the frequency with which it took place was not known so well, particularly in the former case. These very interesting biological phenomena obviously deserve further local and seasonal investigation, in which chemical studies will no doubt be of importance.

\section{Acknowledgements}

It is a pleasure to thank Dr H. B. N. HyNES for collecting the November samples and for arranging a sampling trip in his company to obtain the June series. My gratitude is also owing to Dr J. W. G. LUND for identifying algal samples; to $\mathrm{Mr}$ J. Heron for the nitrate, phosphate and silica analyses; and to the Director of the Freshwater Biological Station, $\mathrm{Mr} \mathrm{H}$. C. Girson, for helpful comments on the manuscript.

\section{REFERENCES}

Clarke, F. W., 1924: The Data of Geochemistry. Bull. U.S. geol. Surv., No. 770.

Conway, E. J., 1942: Mean Geochemical Data in Relation to Oceanic Evolution. Proc. R. Irish Acad., Ser. B, 48, pp. I19-160.

Conway, E. J., I943: The Chemical Evolution of the Ocean. Proc. $R$. Irish Acad., Ser. B, 48, pp. I6I-2I2.

Crompton, E., and Osmond, D. A., 1954: The Soils of the Wem District of Shropshire. Mem. Soil Surv. Gt. Britain, sheet 138. HMSO, London.

Edmunds, F. H., and OAxLey, K. P., 1947: The Central England District, 2nd ed. Handbooks on the Regional Geology of Great Britain. HMSO, London.

ERIKSson, E., 1955: Air Borne Salts and the Chemical Composition of River Waters. Tellus, 7, pp. 243-2 so.

Gorнam, E., 1955: On the Acidity and Salinity of Rain. Geochim. et cosmoch. Arta, 7, pp. 23 I-239.
Grufriths, B. M., I925: Studies in the Phytoplankton of the Lowland Waters of Great Britain. III. The Phytoplankton of Shropshire, Cheshire, and Staffordshire. J. Linn. Soc. (Bot.), 47, pp. 75-98.

Mackereth, F. J. H., I957: In press, Proc. Linn. Soc. Lond.

Penman, H. I., 1950. Evaporation over the British Isles. Quart. J. R. met. Soc., 76, pp. 372-383.

Phillips, W., I883: The Breaking of the Shropshire Meres. Trans. Shropsh. archaeol. nat. Hist. Soc., 7, Pp. 277-300.

Pocock, R. W., and WRAX, D. A., I925: The Geology of the Country around Wem. Mem. geol. Surv. U.K., expl. of sheet 138 .

TAmm, C. O., 1953: Growth, Yield and Nutrition in Carpets of a Forest Moss (Hylocomium splendens). Medd. Skogsforskn.inst. Stockh., 43, pp. 1-140. 